\title{
Reinforcement of Austenitic Manganese Steel with (TiMo) Carbide Particles Previously Synthesized by SHS
}

\author{
Jose Ignacio ERAUSKIN, ${ }^{1)}$ Ara SARGYAN ${ }^{2)}$ and Jose Luis ARANA ${ }^{3)}$ \\ 1) Department of Ferrous Materials, INASMET-Tecnalia, San Sebastian, Spain. E-mail: ierauski@inasmet.es \\ 2) Department of Ceramic Materials, INASMET-Tecnalia, San Sebastian, Spain. E-mail: asargyan@inasmet.es \\ 3) Department of Metallurgical Engineering, Bilbao, Spain. E-mail: jl.arana@ehu.es
}

(Received on September 24, 2008; accepted on January 13, 2009)

\begin{abstract}
The austenite of the Hadfield type manganese steels (1.0-1.4\% C; 12-14\% Mn), even though able to be hardened by impact, explosion, etc., is very ductile, tough and deformable, so that the industrial parts made with this material often suffer important geometric deformations during service. To minimize this problem, it is necessary to reinforce the austenitic matrix with hard, microscopic and dispersed ceramic particles, such as $\mathrm{TiC}$, in order to increase the austenite stiffness while maintaining its toughness. Indeed, the development of a liquid metallurgy process enabling the reinforcement by means of the addition of the ceramic material to the molten metal in the melting furnace would become an important advance in this field. Nevertheless, these ceramic products are prone to the coalescence and have poor wettability by the molten bath, so that, their yield and the subsequent property improvement is very low.

These disadvantages are solved if the ceramic particle is a complex carbide (TiMo)C bonded by metallic $\mathrm{Fe}$, having a masteralloy of the $\mathrm{Fe}(\mathrm{TiMo}) \mathrm{C}$ type made by self-propagated high temperature synthesis (SHS). After that, its addition to the liquid austenitic manganese steel, the pouring of the mix (steel+carbides), its solidification, for example in sand molds, and the subsequent heat treatment (solution annealing and rapid quenching) produces composite castings or parts composed by an austenitic matrix and discrete carbide (TiMo)C particles inserted in it.

This paper describes the process required to fabricate such a material and its characteristics.
\end{abstract}

KEY WORDS: austenitic steel; reinforcement; carbide; masteralloy; SHS.

\section{Introduction}

The ceramic-metal composites, obtained by powder metallurgy and conformed by the insertion of high hardness ceramic elements into the softer metal base matrix, have obtained an ample approval because of their cutting and wear ${ }^{1)}$ resistance properties. Refractory metal carbides such as Titanium, Tungsten or Zirconium carbides $^{2)}$ are the most common ceramic elements used for these applications. On the other hand, the improvements that can be obtained in structural alloys and superficial coating properties such as a higher mechanical and wear resistance, thermal stability, etc., are largely accepted and recognized. ${ }^{3,4)}$

One of the most attractive reinforcing ceramic elements is Titanium carbide because of its high hardness, thermal stability and low density. Unfortunately, it is technically difficult to incorporate these carbide particles into manufactured or semi manufactured metallic alloys, cermets or coating materials due to their low wetability and segregation tendency. ${ }^{5,6)}$ Besides, these particles must have sufficient thermal stability within the alloy matrix at high and low temperatures. ${ }^{7,8)}$

In the last years and within the nonferrous alloys field, aluminium reinforced with silicon carbide particles, ${ }^{9)}$ as well as titanium reinforced with titanium carbide and tita- nium boride ones ${ }^{10)}$ have been developed.

The first attempts to produce ferrous materials reinforced with harder constituents added after its previous synthesis start at the end of the eighties. Hathaway et al., in your "Ferrous Composites: a Review"11) revise the development achieved in this matter (until 1997) both by powder metallurgy process and as liquid metallurgy. On December of 1995 Wood et al. $^{6}$ ) publish a paper and, at the same time, London and Scandinavian Metallurgical Co. Ltd. registers a patent. $^{12)}$ This latter one refers to the synthesis of TiC and (WTi)C with a iron binder, while the paper describes the addition of these carbides to a $0.4 \% \mathrm{C}$ molten steel. More recently, Das et al. ${ }^{13)}$ and Gowtam et al. ${ }^{14)}$ have published papers about austenitic steel reinforced in-situ with titanium carbide. As stated before, the reinforcement of steel with these particles, or with (WTi)C ones, using the liquid metallurgical process, is very difficult due the poor wettability of the system.

On the other hand, the wettability of carbide particles by low carbon, low alloyed steel is increased when the carbide is of (TiMo)C type and is bonded with metallic Fe, giving a $\mathrm{Fe}$ (TiMo)C masteralloy, and this masteralloy is synthesized by self-propagating high temperature synthesis (SHS). ${ }^{15}$ ) Based in this assumption, the present experimental work 
proves the feasibility of the high carbon high manganese austenitic matrix reinforcement with hard, discrete, microscopic (TiMo)C particles metallurgically inserted in the aforementioned matrix.

In this manner, the new "composite" material has higher yield strength and wear resistance, without a pernicious decrease of its impact energy value. Besides, since the stiffness and fatigue limit of the steel are directly influenced by the yield strength, we expect also a considerable increase of these properties.

\section{Experimental}

The process includes the following fundamental steps: a), initial preparation of the reinforcing material, in this case a masteralloy of $\mathrm{Fe}(\mathrm{MoTi}) \mathrm{C}$ type; b), melting of the high carbon high manganese steel bath by means of conventional electric furnace and addition of the masteralloy to the molten steel bath; and c), pouring, solidification and heat treatment of the "composite" product.

\section{a) Masteralloy Synthesis}

The masteralloy is synthesized by self-propagating high temperature synthesis using raw materials containing $\mathrm{Fe}$, $\mathrm{Ti}$, Mo and $\mathrm{C}$. This process allows to obtain products using tiny amounts of energy and with high purity, which is favourable for improving the wettability. The SHS, or materials synthesis by combustion, is based in exothermic chemical reactions solid+solid or solid+gas and the heat generated in the reaction allows it to self-propagate by means of a wave or combustion front. ${ }^{16)}$ A schematic illustration of the process is presented in Fig. 1, and the experimental equipment in Fig. 2.

In the present case, the raw materials, its quantities and characteristics are the following: $12 \%$ pure carbon with a $1-3 \mu \mathrm{m}$ grain size; $73 \% \mathrm{FeTi}(67-70 \% \mathrm{Ti} ; 5 \% \mathrm{Al}$; remainder: $\mathrm{Fe})$, crushed to $100 \mu \mathrm{m}$ grain size; $15 \%$ FeMo $(66 \%$ Mo; $1 \% \mathrm{Si}$; remainder: $\mathrm{Fe}$ ), crushed to $100 \mu \mathrm{m}$ grain size. These three materials are mixed and pressed to $4-6 \mathrm{MPa}$ (the size of the cylindrical sample is a function of the volume of the reactor chamber, in this case we have synthesized blocks of $40 \mathrm{~mm}$ in diameter and $100 \mathrm{~mm}$ in height) and introduced into a steel reactor with argon atmosphere and a wolfram resistance on its edge. The heat of this resistance initiates the reaction and the wave front propagates due to the heat of formation of the masteralloy, synthesizing the total mix. At a macroscopic level, the resultant masteralloy is a brittle and porous material with ceramic aspect.

\section{b) Melting of Steel and Masteralloy Addition}

The base austenitic steel is obtained by induction melting in a $300 \mathrm{~kg}$ of capacity furnace and $1000 \mathrm{~Hz}$ of frequency the following raw materials and quantities: $83 \%$ of carbon steel scrap $(0.15 \% \mathrm{C} ; 0.30 \% \mathrm{Si} ; 0.80 \% \mathrm{Mn} ; \mathrm{P}, \mathrm{S} \leq 0.03 \%)$, $13 \% \mathrm{Fe}-\mathrm{Mn}$ high carbon (7\% C; 70\% Mn) and 4\% Fe-Mn low carbon $(0.5 \% \mathrm{C} ; 70 \% \mathrm{Mn})$. With this starting products we achieve the chemical composition, in $\%$, indicated in the Table 1.

The liquid metallurgical process includes the steps of : raw material melting in the furnace and heating the liquid alloy to $1873 \mathrm{~K}$; addition of the reinforcing material, con-

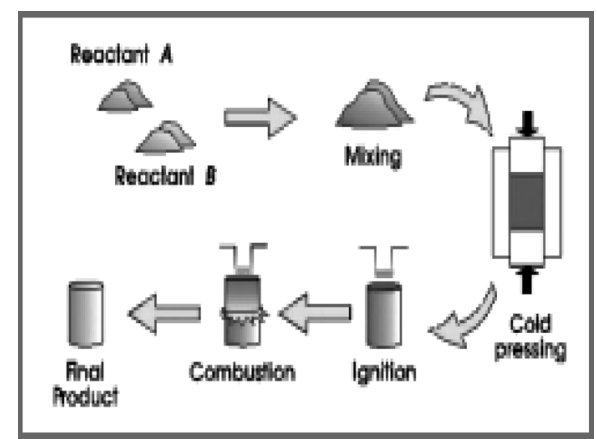

Fig. 1. Typical flow diagram of the SHS process involving solid reactants.

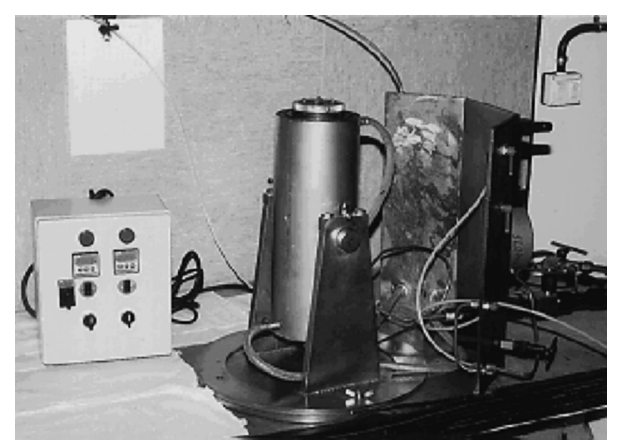

Fig. 2. SHS reactor and equipment.

Table 1. Chemical composition (\% mass) of the base steel.

\begin{tabular}{cccccccc}
\hline $\mathrm{C}$ & $\mathrm{Si}$ & $\mathrm{Mn}$ & $\mathrm{P}$ & $\mathrm{S}$ & $\mathrm{Cr}$ & $\mathrm{Ni}$ & $\mathrm{Mo}$ \\
\hline $1.00-1.20$ & 0.30 & $12.0-14.0$ & 0.035 & 0.010 & - & - & - \\
\hline
\end{tabular}

sisting in $10 \%$ of the base steel weight, of masteralloy $\mathrm{Fe}$ (TiMo)C previously crushed to $2-20 \mathrm{~mm}$ grain size; and heating the bath (steel+carbides) to pouring temperature (about $1823 \mathrm{~K}$ ).

\section{c) Pouring, Solidification and Heat Treatment}

The resulting liquid material, steel alloy+reinforcing carbides, can be poured to produce ingots or castings. In this case, we have obtained sample-blocks solidified in sand molds. Subsequently, they have been heat treated (solution annealing at $1373 \mathrm{~K}$ and rapid quenching in water), in the same way that a conventional austenitic manganese steel. Samples for metallographic and mechanical tests have been prepared from this heat treated material.

The metallographic characterization of this new material has been made by optic and electronic microscopy (SEM with analytical equipment EDS), while hardness, tensile properties, impact energy and tribological properties have been tested using a Vickers microhardness tester FM-100, tensile test machine Instron 8034, Charpy test machine Tinius Olsen model 74 and pin on disk tribometre Biceri (05-168.02).

\section{Results}

\subsection{Masteralloy}

The macroscopic view of the block of the masteralloy 

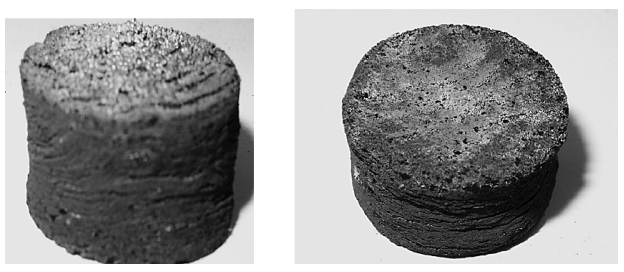

Fig. 3. As synthesized masteralloy $\mathrm{Fe}(\mathrm{TiMo}) \mathrm{C}$ parts.

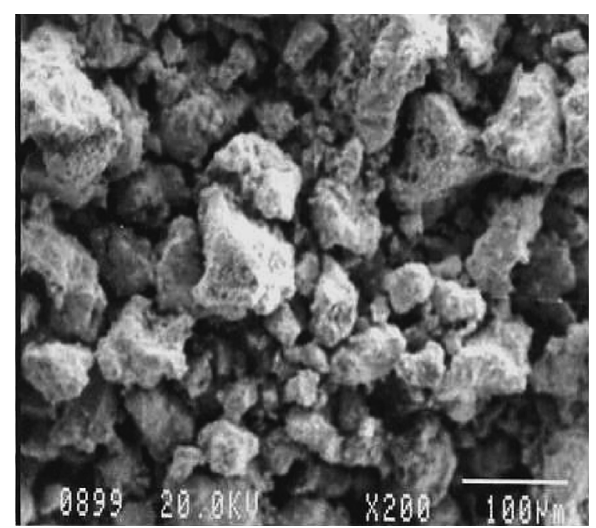

Fig. 4. Crushed masteralloy.

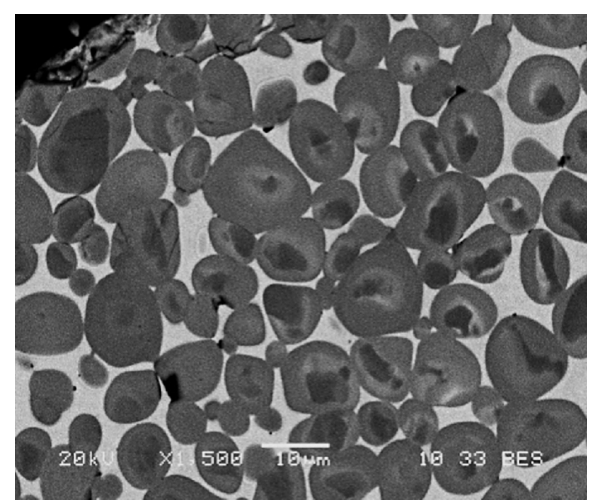

Fig. 5. Sample of polished masteralloy.

produced by SHS is shown in the Fig. 3 .

In the Fig. 4 is presented the microscopic aspect of the masteralloy previously crushed. In both figures we can appreciate the ceramic aspect of the material.

The microstructure of the masteralloy (crushed and polished) is shown in the Fig. 5, where we can see several polygonal-rounded discrete grey particles inserted in a continuous white binder.

Figures 6 and 7 show the spectra of the white constituent (or binder) and the grey particle of the masteralloy, respectively. From them, we can deduce that the white binder is iron, while the grey particles could be a titanium molybdenum complex carbide. The semicuantitative chemical composition (obtained by EDS) of these particles is presented in the Table 2.

Besides these results, the $\mathrm{X}$ ray diffraction tests demonstrate that the grey particles are (TiMo)C type carbides. ${ }^{17)}$

\subsection{Reinforced steel}

\subsubsection{Microstructure}

Figure 8 shows the microstructure (unetched) of the reinforced austenitic steel and Fig. 9 shows the same mi-

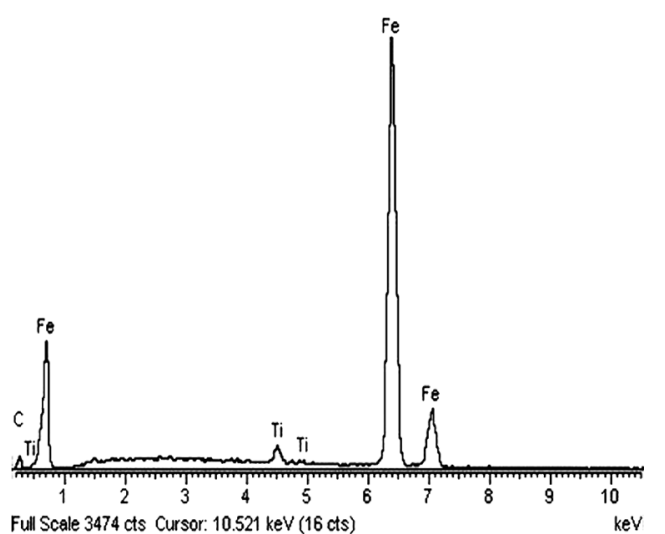

Fig. 6. Masteralloy binder's spectrum.

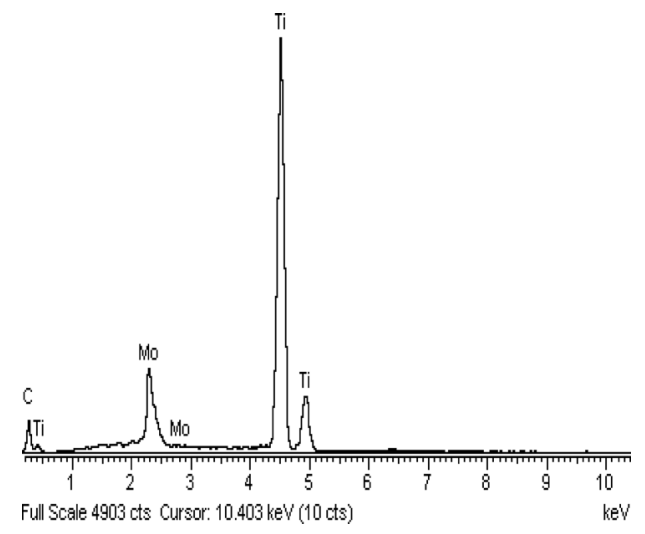

Fig. 7. Masteralloy particle's spectrum.

Table 2. Semicuantitative composition ( $\%$ mass) of the masteralloy grey particles.

\begin{tabular}{lllllll}
\hline Spectrum Label & C & Al & Ti & Fe & Mo & Total \\
& & & & & & \\
\hline & & & & & & \\
Grey particle & 18.43 & & 68.07 & & 13.50 & 100.00 \\
\hline
\end{tabular}

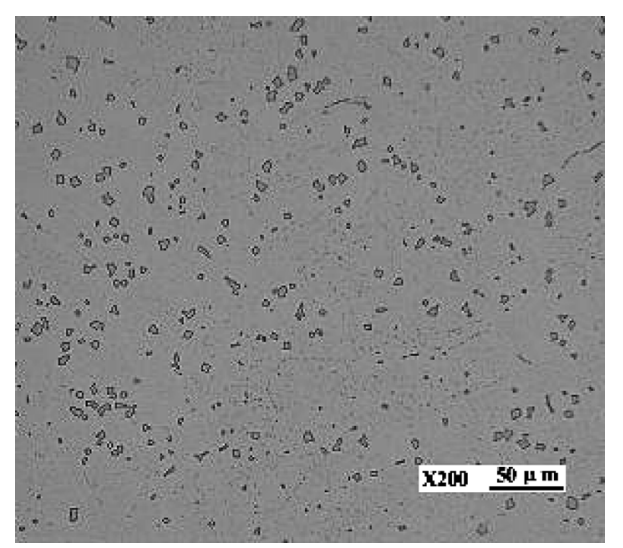

Fig. 8. Microstructure of the reinforced steel (unetched).

crostructure but obtained with an image analyser. In both figures, we can see discrete, microscopic and polygonal particles (dark grey in Fig. 8, blue in Fig. 9) in the matrix (light in Fig. 8, red in Fig. 9).

Figures 10 and 11 show the latter microstructure, etched, at 40 and 400 magnifications respectively, where we can see 


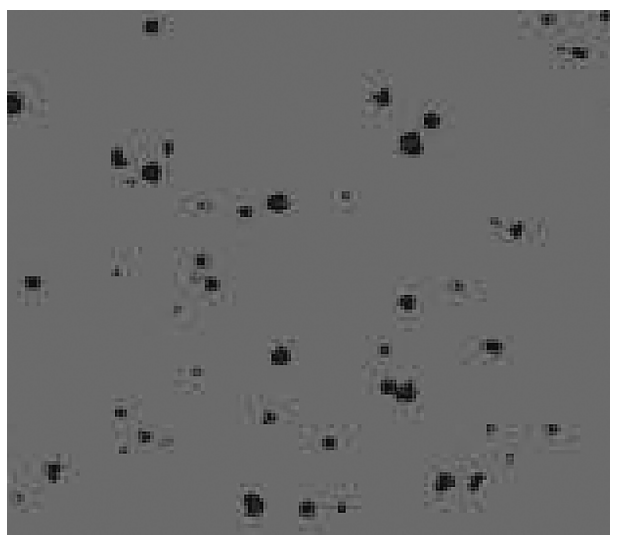

Fig. 9. Microstructure of the reinforced steel $(\times 400)$ using image analyser.

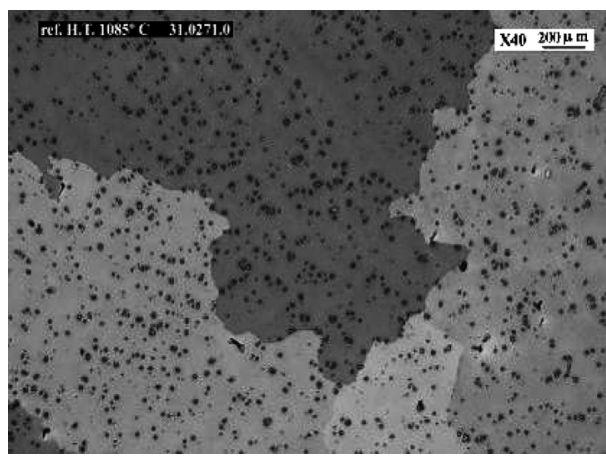

Fig. 10. Microstructure of the reinforced steel.

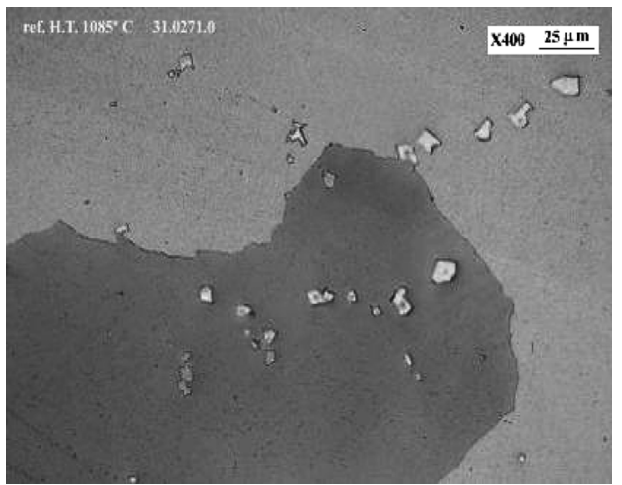

Fig. 11. Microstructure of the reinforced steel.

the former particles inserted within austenite grains.

In Fig. 12 we can see the spectrum of the steel matrix and in the Table 3 its semicuantitative chemical composition. This is the same as the base steel one (high carbon, high manganese, Hadfield type steel of Table 1).

Finally, Fig. 13 shows the spectrum and Table 4 the semicuantitative chemical composition of the particles inserted within the austenitic matrix of the reinforced steel.

From it, we can deduce that these particles could be titanium and molybdenum complex carbides. Their chemical composition (semicuantitative, obtained by EDS) and that of the grey particles of the masteralloy (Table 2) are similar, with a bit more Mo in the former in detriment of the Ti.

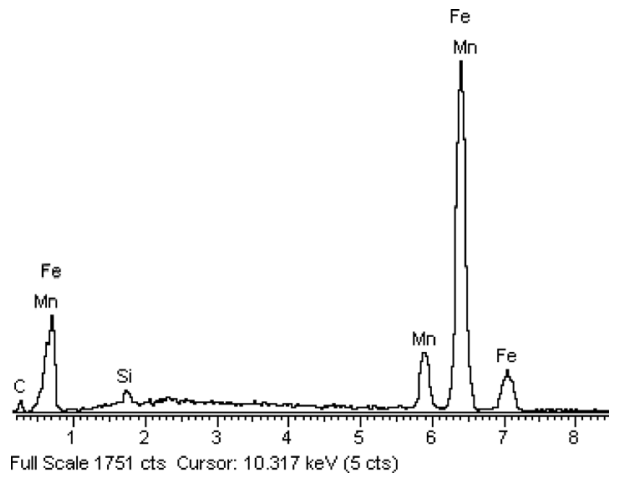

Fig. 12. Spectrum of the austenitic matrix in the reinforced steel.

Table 3. Semicuantitative composition ( $\%$ mass) of the matrix of the reinforced steel.

\begin{tabular}{lllllll}
\hline Spectrum Label & $\mathrm{C}$ & $\mathrm{Al}$ & $\mathrm{Si}$ & $\mathrm{Mn}$ & $\mathrm{Fe}$ & Total \\
\hline
\end{tabular}

\begin{tabular}{llllll} 
Steel matrix & 1.15 & 1.14 & 12.75 & 84.96 & 100.00 \\
\hline
\end{tabular}

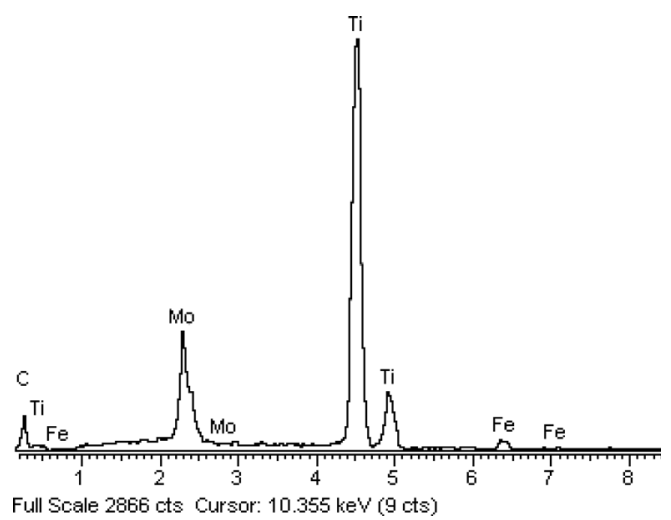

Fig. 13. Spectrum of the polygonal particles in the reinforced steel.

Table 4. Semicuantitative composition ( $\%$ mass) of the particles of the reinforced steel.

\begin{tabular}{lllllll}
\hline Spectrum Label & C & Al & Ti & Fe & Mo & Total \\
& & & & & & \\
\hline Grey particle & 18.62 & & 61.00 & 2.57 & 17.81 & 100.00 \\
\hline
\end{tabular}

Table 5. Mechanical properties of the reinforced steel.

\begin{tabular}{lccccc}
\hline & $\begin{array}{c}\text { Tensile } \\
\text { strength } \\
(\mathrm{MPa})\end{array}$ & $\begin{array}{c}\text { Yield } \\
\text { strength(0.2\%) } \\
(\mathrm{MPa})\end{array}$ & $\begin{array}{c}\text { Elongation } \\
(\%)\end{array}$ & $\begin{array}{c}\text { Reduction } \\
\text { of area } \\
(\%)\end{array}$ & $\begin{array}{c}\text { Impact } \\
\text { energy } \\
(\mathrm{J})\end{array}$ \\
\hline $\begin{array}{l}\text { Conventional } \\
\text { steel }\end{array}$ & 636 & 371 & 35 & 41 & 162 \\
\hline $\begin{array}{l}\text { Reinforced } \\
\text { steel }\end{array}$ & 575 & 482 & 16 & 22 & 128 \\
\hline
\end{tabular}

\subsubsection{Mechanical properties}

3.2.2.1. Hardness. The microhardness values of the polygonal particles inserted in the austenitic grains of the reinforced steel are between 2400 and $3100 \mathrm{HV}_{0.025}$. These high values indicate that the particles are carbides.

3.2.2.2. Tensile and Charpy Tests. In the Table 5 we can see the values obtained (made according to the standard 
Table 6. Wear behaviour.

\begin{tabular}{lcc}
\hline & Hadfield steel & Reinforced steel \\
\hline Wear rate $\left(\mathrm{mm}^{3} / \mathrm{N} \cdot \mathrm{m}\right)$ & $6.8 \cdot 10^{-8}$ & $3.5 \cdot 10^{-8}$ \\
\hline
\end{tabular}

EN-ISO 6506-1) for Hadfield conventional steel and the reinforced steel of this work.

From these values we can deduce the reinforced steel is less tough and ductile than the conventional one, although its toughness is certainly enough for a satisfactory behaviour under impact conditions. On the other hand, the yield strength value of the reinforced steel is higher.

\subsubsection{Wear Resistance}

It has been evaluated by means of the pin (of martensitic steel) on disk test on the conventional and reinforced steel samples, during $30 \mathrm{~h}$ under a normal stress of $90 \mathrm{MPa}$ $\left(\mathrm{N} / \mathrm{mm}^{2}\right)$ and $150 \mathrm{rpm}$. The results, in wear rate of the disks, are in the Table 6.

From them, we can deduce that the wear resistance (under stress) of the reinforced austenitic steel is twice the conventional one.

\section{Conclusions}

From the microstructures (Figs. 6, 7, 8), the spectrum (Fig. 9, Table 4) and the microhardness values (point 3.2.2.1), we can deduce that the particles inserted within austenite grains of the reinforced steel are (TiMo)C carbides.

We can thus assure that these carbides are just the same grey particles present in the carbide of the masteralloy $\mathrm{Fe}$ (TiMo)C added to the steel. The small difference in composition is not representative because the EDS semicuantitative analysis is not exact. Likewise, the small change in shape (less rounded in the steel) is due to action of the molten steel.

The mechanism of formation of the composite steel+ carbides is the next: When the masteralloy Fe(TiMo)C contacts the liquid steel (iron base), the binder $\mathrm{Fe}$ of the former melts and adds up to the metallic alloy, while the (TiMo)C particles, separated already from the binder and wetted by the liquid, remain embedded within it. Due to its high refractoriness and thermal stability, the carbide particles are not changed much even after the heat treatment of the solid material.

The polygonal titanium-molybdenum carbides, inserted metallurgically within the very ductile and tough austenite grains, lower some mechanical characteristics (elongation, reduction of area, etc.). However, the impact energy values of the new material are sufficiently high for the expected service conditions of the typical components made in Hadfield steel (railway crossings, crushing jaws, hammers), so that, there is no risk of component fracture if this reinforced steel is used.

Besides, the beneficial effect of the carbides on the properties of the reinforced austenite such as deformability (expected to be lower, due to lower elongation), stiffness (expected to be higher, due the same reason as before), fatigue resistance (expected to be higher, due to higher yield strength), and wear resistance (clearly higher) are very interesting and promising in order to solve the characteristic shortcomings of the austenitic Hadfield steel.

In summary, the main conclusions of the present experimental work are:

(1) The powder metallurgy process SHS allows the manufacture of a masteralloy $\mathrm{Fe}(\mathrm{TiMo}) \mathrm{C}$ wettable by molten steel and composed by particles of complex carbide in an iron binder.

(2) The addition of this masteralloy to a molten Hadfield steel bath and the subsequent solidification and heat treatment of the mix, allows the insertion of the complex carbide particles (TiMo)C of the masteralloy within the austenite grains of the steel.

(3) This insertion produces a reinforcement of the austenitic matrix, with an appreciable increase in yield strength and wear resistance, but keeps the values of the other properties, such as elongation and impact energy, within adequate levels.

\section{REFERENCES}

1) J. R. Tinklepaugh and W. B. Crandall: Cermets, Reinhfold Publishing Corporation, New York, (1960), 146.

2) W. M. Steen: Future Developments of Metals and Ceramics, Institute of Materials, London, (1992), 261.

3) P. Chesney: Met. Mater, 6 (1990), 373.

4) A. Kelly and N. H. Macmillan: Strong Solids, Clarendon Pr, Oxford, (1987), 332.

5) B. S. Terry and O. S. Chinyamakobvu: Mater. Sci. Technol., 8 (1992), 399.

6) J. V. Wood, K. Dinsdale, P. Davies and J. L. F. Kellie: Mater. Sci. Technol., 11 (1995), 1315.

7) H. J. Heine: Foundry Manage. Technol., 85 (1987) 25.

8) T. Z. Kattamis and T. Suganuma: Mater. Sci. Eng. A, A128 (1990), 241.

9) M. G. de Cortazar: Doctoral Thesis, Université Bordeaux, (2006), 107.

10) X. Zhang, W. Lü, D. Zhang and R. Wu: Scr. Mater, 41 (1999), 39.

11) R. M. Hathaway, P. K. Rohatgi, N. Sobczak and J. Sobczak: Ferrous Composites: A review, Proc. Int. Conf. High Temperature Capillarity, Cracow, (1997).

12) Metal Matrix Alloys: Patent WO 93/03192 (1993).

13) K. Das, T. K. Bandyopadhyay and S. Chatterjee: J. Mater. Sci., 40, (2005), No. 18, 5007.

14) D. S. Gowtam, M. Ziyauddin, M. Mohape, S. S. Sontakke, V. P. Deshmukh and A. K. Shah: International Journal of Self-Propagating High Temperature Synthesis, 16 (2007), 70.

15) I. Agote, M. Gutierrez, M. Orbegozo, M. Asensio, J. I. Erauskin, L. A. Erausquin and J. Roncal: Rev. Metal. Madrid, Volumen Extraordinario (2005), 53

16) U. A. Tamburini, F. Maglia, G. Spinolo and Z. A. Munir: Chimica \& Industria, 82 (2000), 1.

17) Product Manufacture in Structural Metallic Materials Reinforced with Carbides, Patent WO 03042419 (2004). 